\title{
COMMENTS
}

\section{THE HAGUE GONVENTION ON THE TAKING OF EVIDENGE ABROAD IN GIVIL OR COMMERCIAL MATTERS: THE EXCLUSIVE AND MANDATORY PROCEDURES FOR DISCOVERY ABROAD}

\section{INTRODUCTION}

Lawsuits involving foreign parties present American litigants and courts with unique problems. In addition to questions of jurisdiction over the foreign parties and choice of law, one of the most persistent and challenging problems has been to determine the procedure by which evidence located in foreign nations may be obtained.

American courts have long struggled with the legal questions raised when an American discovery rule or policy is frustrated by foreign statutes or procedures governing the taking of evidence abroad. ${ }^{1}$ These cases have typically involved confrontations with foreign "blocking statutes," which impose a variety of civil or criminal penalties for the removal of evidence from the country. When a party asserts a foreign blocking statute as a defense to a discovery request, a court is faced with a choice between denying the discovery requested or ordering the commission of acts that violate the law of the situs of the evidence. ${ }^{2}$

1 For a survey of the history of United States recognition of foreign laws when in conflict with American policies, see Onkelinx, Conflict of International Jurisdiction: Ordering the Production of Documents in Violation of the Law of the Situs, 64 Nw. U. L. REv. 487 (1969); Note, Discovery of Documents Located Abroad in U. S. Antitrust Litigation: Recent Developments in the Law Concerning the Foreign Illegality Excuse for Non-Production, 14 VA. J. INT'L L. 747 (1974); Note, Foreign Nondisclosure Laws and Domestic Discovery Orders in Antitrust Litigation, 88 YALE L.J. 612 (1979).

2 See, e.g., Société Internationale Pour Participations Industrielles et Commerciales, S.A. v. Rogers, 357 U.S. 197 (1958) (although liability under a foreign non-disclosure law does not automatically excuse compliance with a valid discovery order, dismissal or similarly harsh sanctions should not be used when a party makes a good faith effort to comply but is unable because of a foreign blocking statute); FTC v. Compagnie de Saint-Gobain-Pont-A-Mousson, 636 F.2d 1300 (D.C. Cir. 1980) (service of subpoena by Federal Trade Commission upon French corporation invalid); In re Westinghouse Elec. Corp. Uranium Contracts Litig., 563 F.2d 992 (10th Cir. 1977) (contempt order overturned since defendant made a diligent effort to obtain waiver of Canadian regulation precluding discovery); Arthur Anderson \& Co. v. Finesilver, 546 F.2d 338 (10th Gir. 1976), cert. denied, 429 U.S. 1096 (1977) (discovery orders valid even though compliance would allegedly violate foreign nondisclosure laws); United States v. First Nat'l City Bank, 396 F.2d 897 (2d Cir. 1968) (same); In re Chase Manhattan Bank, 297 F.2d 611 (2d Cir. 1962) (where compliance with subpoena would violate foreign law, subpoena was properly modified but bank must comply with its duty of 
In recent years, American courts have encountered a new dimension to the problem of obtaining foreign evidence. The difficulty arises when litigants insist that foreign discovery can proceed only according to the provisions of the Hague Convention on the Taking of Evidence Abroad in Civil or Commercial Matters ${ }^{3}$ [Hague Evidence Convention]. Courts presented with this argument must address a conflict between the discovery provisions of a treaty to which the United States is a signatory and the domestic discovery provisions and policies embodied in the Federal Rules of Civil Procedure or similar state discovery statutes or rules. ${ }^{4}$ Courts in the United States have resisted interpreting the Hague Evidence Convention as providing an exclusive mechanism for obtaining evidence from signatory states. Instead, they have viewed the Convention as offering discretionary procedures that an American court ordering discovery abroad may disregard in favor of procedures authorized by federal or state discovery rules.

This Comment asserts that the Hague Evidence Convention was intended to establish the sole mechanism by which evidence situated in signatory nations may be obtained. The Comment first briefly describes

actively cooperating with the government to obtain the documents for discovery).

3 The Hague Convention on the Taking of Evidence Abroad in Civil or Commercial Matters, done March 18, 1970, 23 U.S.T. 2555, T.I.A.S. No. 7444 [hereinafter cited as Hague Evidence Convention]. Actually, a defense to a discovery request asserting the Hague Evidence Convention often is combined with a foreign blocking statute defense by claiming that discovery other than through the provisions of the Hague Evidence Convention would constitute a violation of the blocking statute. See, e.g., Continental Prods. Corp., 569 F. Supp. 1227 (E.D. Pa. 1983); Kantor v. Cycles Peugeot, S.A., No. 81-0423, slip op. (D.R.I. April 14, 1982); Pierburg GmbH \& Co. KG v. Superior Court, 137 Cal. App. 3d 238, 186 Cal. Rptr. 876 (Cal. Ct. App. 1982); Volkswagenwerk Aktiengesellschaft v. Superior Court, 123 Cal. App. 3d 840, 176 Cal. Rptr. 874 (Cal. Ct. App. 1981).

- Besides the different interpretation and construction problems presented by a conflict between the Hague Evidence Convention and American discovery procedures, there are significantly different policy considerations involved. The leading blocking statute cases have involved important substantive policy concerns in addition to the policies favoring the availability of liberal discovery procedures. See, e.g., Société Internationale Pour Participations Industrielles et Commerciales, S.A. v. Rogers, 357 U.S. 197, 207 (1958) (enforcement of policies behind Trading with the Enemy Act following World War II); United States v. First Nat'l City Bank, 396 F.2d 897 (2d Cir. 1968) (enforcement of United States antitrust policies); In re Chase Manhattan Bank, 297 F.2d 611 (2d Gir. 1962) (enforcement of tax laws); Montship Lines, Ltd. v. Federal Maritime Bd., 295 F.2d 147 (D.C. Cir. 1961) (Federal Maritime Board enforcement procedures); Ings v. Ferguson, 282 F.2d 149 (2d Cir. 1960) (shareholders' derivative action); First Nat'l City Bank v. IRS, 271 F.2d 616 (2d Cir. 1959) (investigation of federal tax liability of Panamanian corporation with offices in New York City); In re Grand Jury Investigation of the Shipping Industry, 186 F.Supp. 298 (D.D.C. 1960) (enforcement of antitrust policies). These substantive policy considerations have been absent from the Hague Evidence Convention cases, all of which have involved litigation between private parties with no special policy considerations. Of course, there is no reason why such a pattern would necessarily continue. 
some of the differences between civil and common law procedures for gathering evidence. It then outlines the key provisions of the Convention addressing those differences. The second part of the Comment analyzes American judicial interpretation of the Convention. The third part of the Comment applies basic principles of treaty interpretation to the Convention and concludes that the drafting nations, including the United States, intended that the Convention establish the exclusive means for taking evidence abroad. The Comment concludes that since the Convention takes precedence over federal and state rules of civil procedure, American courts may only order discovery pursuant to the terms of the Hague Evidence Convention.

\section{The Hague Evidence Convention}

The Hague Evidence Convention was produced in 1968 at the Eleventh Session of the Hague Conference on Private International Law. Twenty-five nations participated in negotiating and drafting the document. ${ }^{\circ}$ To date, the Convention has been entered into force in seventeen nations including the United States. ${ }^{7}$

- See Message from the President Transmitting to the Senate the Convention on the Taking of Evidence Abroad in Civil of Commercial Matters, S. ExEc. Doc. A at III, 92d Cong., 2d Sess. (Feb. 1, 1972), reprinted in 12 INT'I Legal Materials 323 (1973) [hereinafter cited as Message from the President]. The Hague Evidence Convention was drafted following the earlier developments of the Hague Convention on the Service Abroad of Judicial and Extra-Judicial Documents in Civil or Gommercial Matters, done November 15, 1965, 20 U.S.T. 361, T.I.A.S. No. 6638, 658 U.N.T.S. 165, reprinted in FED. R. Grv. P. 4(i) [hereinafter cited as Hague Documents Convention]. The Hague Documents Convention was undertaken as a comprehensive revision of chapter I of the Hague Civil Procedure Convention of 1954, which had superseded the Hague Civil Procedure Convention of 1905, both of which were adopted before the United States joined the Hague Conference on Private International Law. See Amram, United States Ratification of the Hague Convention on the Taking of Evidence Abroad, 67 AM. J. INT'L L. 104, 104 (1973); Note, The Hague Convention on the Taking of Evidence Abroad in Civil or Commercial Matters - A Comparison with Federal Rules Procedures, 7 BRookLyn J. INT'L L. 365, 369 n.25 (1981) [hereinafter cited as Note, Comparison with Federal Rules].

- The Convention was signed by Austria, Belgium, Canada, Czechoslovakia, Denmark, Finland, France, Greece, Great Britain, Ireland, Israel, Italy, Japan, Luxembourg, the Netherlands, Norway, Portugal, Northern Ireland, Sweden, Switzerland, Spain, Turkey, the United Arab Republic, the United States, and Yugoslavia on April 17, 1970. Hague Evidence Convention, supra note 3, 23 U.S.T. at 2576-77.

7 Barbados, Cyprus, Czechoslovakia, Denmark, Finland, France, the Federal Republic of Germany, Israel, Italy, Luxembourg, the Netherlands, Norway, Portugal, Singapore, Sweden, the United Kingdom (including the possessions of Hong Kong, Gibralter, areas of Akrotiri and Dhekelia in the island of Cyprus, and the Faulkland Islands), and the United States (including Guam, Puerto Rico, and the Virgin Islands). 7 Martindale-Hubbell Law Directory, pt. 7, at 14, 18-19 (1984). 


\section{A. Background}

One of the primary purposes of the Convention was to fill "the need for an effective international agreement to set up a model system to bridge differences between the common law and civil law approaches to the taking of evidence abroad."8 These differences are significant. One of the more important differences is that the technique of pretrial discovery by private parties that has developed in the United States is unknown in civil law countries. ${ }^{9}$ This issue has infused tension into international judicial proceedings involving American parties. ${ }^{10}$

A second important difference is that, in civil law countries, the taking of evidence is conducted largely by the courts. Evidence is gathered for trial not by private lawyers conducting interrogatories and depositions, but by judges who choose which witnesses to interview and what questions to ask. After questioning the witnesses, the judge prepares a summary record of the evidence. No verbatim transcript of testimony is kept. ${ }^{11}$ Moreover, in the United States the gathering of evidence for use in a lawsuit involving a foreign party is a purely private matter so long as it does not involve compulsion or a breach of the peace; in civil law countries an attempt by a private party to gather evidence for use in a proceeding abroad may be an illegal usurpation of

8 Letter of Submittal from Secretary of State William P. Rogers to the President Regarding the Evidence Convention, S. ExEc. Doc. A., at V, 92d. Cong., 2d Sess. (Feb. 1, 1972), reprinted in 12 INT'I LEGAL MATERIALS 324 (1973) [hereinafter cited as Letter of Submittal].

In fact, the differences among common law countries have proven to be almost as difficult to bridge. There have been well-publicized conflicts over American attempts to enforce its policies abroad, especially in the antitrust area, see, e.g., Rio Tinto Zinc Corp. v. Westinghouse Elec. Corp. [1978] 1 All E.R. 434 (letter of request from American court rejected because of potential use of evidence in criminal proceeding, which is not a civil or commercial matter, and because of perceived threat to British sovereignty from antitrust proceeding). There have also been disagreements between the United States and the United Kingdom over the permissible scope of pretrial discovery. This difference of opinion led to the inclusion of Article 23 in the Hague Evidence Convention at the United Kingdom's request. See infra note 35.

- "Pre-trial disclosure as known in common law countries, and especially as known in the U.S., is unheard of [in civil law countries]." Practising Law INSTITUTE, EXTRATERRITORIal Discovery in INTERNATIONAL LITIGation (1984).

10 See infra note 35.

11 See Note, Obtaining Testimony Outside the United States: Problem for the California Practitioner, 29 HASTings L.J. 1237, 1247 (1978). See generally R. Schlesinger, Comparative Law: Gases-Test-Materials 308-21 (3d ed. 1970); Jones, International Judicial Assistance: Procedural Chaos and a Program for Reform, 62 YALE L.J. 513, 527-28 (1953) (both Schlesinger and Jones are cited in Note, supra). For descriptions of evidence-gathering in specific civil law countries, see Borel \& Boyd, Opportunities for and Obstacles to Obtaining Evidence in France for Use in Litigation in the United States, 13 INT'L LAw. 35, 36-37 (1979); Shemanski, Obtaining Evidence in the Federal Republic of Germany: The Impact of the Hague Evidence Convention on German-American Judicial Cooperation, 17 INT'L LAw. 465, 466-68 (1983). 
a "public judicial" function, and considered an affront to that nation's "judicial sovereignty."12 Recognizing these differences, the drafters of the Convention sought to establish a method for taking evidence that would be both "tolerable" to the state where evidence is situated and "utilizable" in the forum state. ${ }^{18}$

While addressing these differences, participants at the Convention also sought to replace a system of international evidence-taking based on vague and imprecise principles of comity and reciprocity ${ }^{14}$ with a treaty that would better serve the purpose of accomodating the different judicial systems. Whereas United States participation in drafting the Convention was prompted by the frustration American lawyers had long experienced in their efforts to obtain evidence in foreign nations, ${ }^{15}$ foreign participation stemmed from a perception of excessively broad discovery efforts by United States litigants and courts. The Hague Evidence Convention, therefore, is best understood as a compromise between judicial systems with very different attitudes toward discovery

${ }^{12}$ Report of the United States Delegation to the Eleventh Session of Hague Conference on Private Int'l Law, 8 INT'L LEGAL Materials 785, 806 (1969) [hereinafter cited as 1969 Report of the U.S. Delegation].

131969 Report of the U.S. Delegation, supra note 12, at 806. For additional details of the history of the Hague Evidence Convention, see id. at 804-08; Amram, The Proposed Convention on the Taking of Evidence Abroad, 55 A.B.A. J. 651 (1969); Message From the President, supra note 5.

${ }_{14}$ See Augustine, Obtaining International Judicial Assistance Under the Federal Rules and the Hague Convention on the Taking of Evidence Abroad in Civil and Commercial Matters: An Exposition of the Procedures and a Pratical Example: In re Westinghouse Uranium Contract Litigation, 10 GA. J. INT'L \& CoMP. L. 101, 122 (1980).

International comity has been defined by one court as

[t]he concept that the courts of one sovereign state should not, as a matter of sound international relations, require acts or forebearances within the territory, and inconsistent with the internal laws, of another sovereign state unless a careful weighing of competing interests and alternative means makes clear that the order is justified.

Volkswagenwerk Aktiengesellschaft v. Superior Court, 123 Cal. App. 3d 840, 857, 176 Cal. Rptr. 874, 884 (Cal. Ct. App. 1981). See also Schroeder v. Lufthansa German Airlines, 18 Av. Cas. (CCH) 17,222, 17,223 (N.D. Ill. Sept. 15, 1983).

Perhaps the most pervasive problem of a system of international discovery relying on unspecific concepts of comity is the lack of precise standards governing the balancing of competing interests. Indeed, as one commentator has persuasively argued, "the balancing test [of international comity] usually allows the concern for full discovery to dominate over all other concerns." Note, Foreign Nondisclosure Laws and Domestic Discovery Orders in Antitrust Litigation, 88 YALE L.J. 612, 621 (1979). In supplying specific procedures with which contracting states have agreed in advance to comply, the Hague Evidence Convention gives concrete substance to the valuable concept of balancing competing interests. This is a clear improvement over an uncertain system based on international comity.

16 See generally Letter of Submittal, supra note 8, at VI, 12 INT'L LEGaL MATERIALs at 324; Amram, supra note 13, at 651. 
and the taking of evidence.

\section{B. Key Provisions}

The Hague Evidence Convention establishes three basic methods for obtaining evidence from foreign nations: letters of request, ${ }^{16}$ use of diplomatic or consular officials, ${ }^{17}$ and use of designated private commissioners. ${ }^{18}$

Chapter I of the Convention sets forth the procedures governing letters of request. A letter of request seeks foreign judicial assistance in the taking of evidence abroad. An American litigant, for example, files a letter of request in the federal or state court (the requesting court) in which the suit is being heard. The letter is transmitted, either through the Department of Justice or directly to the designated "central authority" in the state from which evidence is sought (the receiving state). From this central authority, the request is forwarded to the judicial authority in the foreign state competent to execute it. These letters of request can be used to conduct examinations of persons, ${ }^{10}$ address specific questions to witnesses, ${ }^{20}$ and inspect documents and personal or real property. ${ }^{21}$

Article 9 of the Convention provides that, normally, the receiving state's laws and procedures will govern the execution of letters of request. The receiving state is bound, however, to comply with requests to use a "special method or procedure" in the gathering of evidence, unless such request is either "incompatible" with the receiving state's internal law or "impossible of performance [under] internal practice or procedure." ${ }^{\text {22 }}$ An internal statute or procedure that is merely different is not grounds for refusing to comply with a request for a special procedure under Article 9; there must be an "absolute statutory prohibition" or "constitutional limitation."

16 Hague Evidence Convention, supra note 3, at chapter I.

17 Id. at chapter II.

18 Id. For more detailed descriptions of the provisions of the Convention, see Augustine, supra note 14, at 120-33; Note, Comparison with Federal Rules, supra note 5, at 374-409; see also 1969 Report of the U.S. Delegation, supra note 12, at 807; Explanatory Report on Convention on the Taking of Evidence Abroad in Civil or Commercial Matters, S. Exec. Doc. A at 11, 92d Cong., 2d Sess. (Feb. 1, 1972), reprinted in 12 INT'L Legal Materials 327 (1973) [hereinafter cited as Rapporteur's Report].

19 Hague Evidence Convention, supra note 3, at Article 3(e).

${ }^{20} \mathrm{Id}$. at Article 3(f).

21 Id. at Article 3(g).

$22 \mathrm{Id}$. at Article 9. For example, a special request might be made that an oath be administered before a witness was questioned or that a verbatim transcript be taken. See Note, Comparison with Federal Rules, supra note 5, at 388-89.

ss Moreover, "impossibility" rather than "impracticability" is required in order 
Article 10 provides that the receiving state's measures of compulsion must be applied to the same extent in executing a foreign letter of request as in enforcing an order by its own authorities in an internal proceeding. ${ }^{24}$ Under Article 11, a witness may assert a privilege to refuse to give evidence under the law of either the state of origin or the receiving state. ${ }^{25}$

Article 12 provides that the receiving state may refuse to execute a letter of request only if the request cannot be executed by the judiciary of the receiving state (that is, if it requests an act beyond the power or competence of the judiciary of the receiving state) ${ }^{26}$ or if the receiving state considers that its sovereignty or security would be prejudiced by complying with the request. ${ }^{27}$ Article 12 further provides that a receiving state may not refuse to execute a letter of request merely because it claims exclusive jurisdiction over the subject matter of the action or because its laws do not recognize the cause of action involved.

Chapter II of the Convention sets forth the procedures by which diplomatic officers, consular agents, and designated commissioners may take evidence in signatory nations. Depending on whether the receiving state has made a reservation permitted by the Convention, the taking of evidence by these officials may require prior permission from the central authority of that state. ${ }^{28} \mathrm{~A}$ major limitation on chapter II mechanisms of evidence-gathering is that compulsion against recalcitrant witnesses is not generally available. Although Article 18 provides that a state may make a declaration that foreign courts requesting evidence may apply to the declaring state's central authority for assistance in compelling the giving of evidence before consular agents or commission$\mathrm{ers}^{29}$ only four of the seventeen nations that have signed the treaty have made such a declaration. ${ }^{30}$ Thus, the taking of evidence by consular agents or private commissioners under the Convention is likely to be feasible only if the witness is willing to testify. ${ }^{31}$

Chapter III of the Convention contains several general clauses that

for a receiving state to refuse a request for a special procedure under Article 9. Rapporteur's Report, supra note 18, at 23-24, 12 INT'L Legal MATERIALS at 333. See also 1969 Report of the U. S. Delegation, supra note 12, at 810-11.

24 Hague Evidence Convention, supra note 3, at Article 10.

25 Id. at Article 11.

${ }^{20}$ Id. at Article 12(a).

27 Id. at Article 12(b).

28 Id. at Articles 15-17.

29 Id. at Article 18.

so Czechoslovokia, Italy, the United Kingdom, and the United States have made such a declaration. 7 Martindale-Hubbell LAW Directory, pt. 7, at 14-20 (1984).

${ }^{31}$ See Note, Comparison with Federal Rules, supra note 5, at 379. 
apply to the Convention as a whole. A key provision of chapter III is Article 32, which provides that "the present Convention shall not derogate from [treaties] containing provisions on the matters covered by this Convention to which the Contracting States are, or shall become Parties." abroad under mechanisms established by other treaties to which the signatories of the Hague Evidence Convention have agreed.

Courts and commentators have focused particular attention on Articles $23^{33}$ and $27^{34}$ as support for an interpretation that the Convention establishes discretionary mechanisms for foreign discovery. Article 23 provides that "[a] Contracting State may ... declare that it will not execute Letters of Request issued for the purpose of obtaining pretrial discovery of documents as known in Common Law countries." ${ }^{\text {"35 }}$ Ac-

32 Hague Evidence Convention, supra note 3, at Article 32.

s3 Id. at Article 23; see Lasky v. Continental Prods. Corp., 569 F. Supp. 1227, 1229 (E.D. Pa. 1983); Batista, Confronting Foreign "Blocking" Legislation: A Guide to Securing Disclosure From Non-resident Parties to American Litigation, 17 INT'L LAw. 61, 67-69 (1983); see also Philadelphia Gear Corp. v. American Pfauter Corp., No. 82-5500, slip op. at 5-6 (E.D. Pa. Nov. 16, 1983).

s4 Hague Evidence Convention, supra note 3, at Article 27; see Lasky v. Continental Prods. Corp., 569 F. Supp. 1227, 1228 (E.D. Pa. 1983); Piersburg GmbH \& Co. v. Superior Court, 137 Cal. App. 3d 238, 244, 186 Gal. Rptr. 876, 880 (Gal. Ct. App. 1982); Volkswagenwerk Aktiengesellschaft v. Superior Court, 123 Cal. App. 3d 840, 859, 176 Cal. Rptr. 874, 886 (Cal Ct. App. 1981); Batista, supra note 33, at 79.

85 Hague Evidence Convention, supra note 3, at Article 23.

At least one American court has pointed to the existence of an Article 23 declaration and decided that the Convention cannot provide the only means for obtaining foreign evidence. In Lasky v. Continental Prods. Corp., 569 F. Supp. 1227 (E.D. Pa. 1983), the court discussed West Germany's Article 23 reservation, see id. at 1229 ("Germany] will not execute letters of request for the purpose of obtaining pretrial discovery of documents"), and stated that limiting discovery solely to the procedures established by the Convention "would severely restrict the plaintiffs' scope of discovery," id.

Other considerations, however, contributed to this conclusion. West Germany has not made an Article 18 declaration that it would provide assistance in compelling witnesses to give evidence before consular agents or private commissioners. In fact, West Germany has made an Article 33 declaration that prohibits the taking of evidence from German nationals by consular agents or private commissioners. 7 MARTINDALE-HuBBELL LAW DIRECTORY, pt. 7, at 16 (1984). Obtaining pretrial discovery of documents in West Germany pursuant to the terms of the Convention, therefore, is a difficult matter. Pretrial discovery from West Germany in any other manner, however, is likely to be just as difficult.

Article 23 reservations are not generally so troubling. Of the 17 signatory nations, five (Barbados, Cyprus, Czechoslovakia, Israel, and the United States) have made no Article 23 declarations blocking pretrial discovery of documents. Seven other nations (Denmark, Finland, the Netherlands, Singapore, Sweden, and the United Kingdom) have adopted limited Article 23 declarations patterned after the British reservation. Id. at 14-20. The British declaration provides that the United Kingdom will not execute letters of request issued for the purpose of obtaining pretrial discovery of documents but is restricted so as to apply only to letters of request that require a person

a. to state what documents are relevant to the proceedings to which the 
cording to Article 27, the other clauses of the Convention do not prohibit participating nations from "(b) permitting, by internal law or practice, any act provided for in this Convention to be performed under less restrictive conditions" and "(c) permitting, by internal law or practice, methods of taking evidence other than those provided for in this Convention."36 Article 27 clearly permits a state in which evidence is situated to allow the gathering of evidence under its less restrictive practices. There is some disagreement, however, about whether Article 27 confers discretion upon a state seeking evidence to order discovery in a manner not specified in the Convention. ${ }^{37}$

The language of the Hague Evidence Convention does not clearly indicate whether the Convention was intended to establish exclusive procedures by which a court seeking foreign evidence can order discovery abroad. Because the Convention itself is not clear on this issue and

Letier of Request relates are, or have been, in his possession, custody, or power; or

b. to produce any documents other than particular documents specified in the Letter of Request as being documents appearing to the requested court to be, or to be likely to be, in his possession, custody, or powers.

Id. at 18. Such restricted Article 23 declarations are designed only to prevent nonspecific fishing expeditions for evidence; they do not bar pretrial requests for production of specific documents. See Report on the WORK of THE Special Commission on THE Operation OF the Convention of 18 MARch 1970 on the TakIng OF EviDENCE ABROAD IN CIVIL OR COMMERCIAL MATTERS, June 12-15, 1978, reprinted in 17 Int'l Legal Materials 1425, $1427-28$ (1978) [hereinafter cited as Spectal Commission RePort]; see also Office of the Legal Advisor, Departament of State, Digest of United States Practice in IN'T'L Law 873-75 (1978) [hereinafter cited as DiGEST].

The remaining five nations (France, West Germany, Italy, Luxembourg, and Portugal) have adopted Article 23 declarations that appear to preclude pretrial discovery of all documents, regardless of whether the request is for specific documents or not. 7 Martindale-Hubbell Law Directory, pt. 7, 14-20 (1984). Some of these countries, however, may decide to adopt limited Article 23 declarations. In 1978, the Special Commission met at the Hague to review the operation of the convention and concluded that many civil law countries had made Article 23 declarations because of a misunderstanding that "pretrial discovery" referred to "some sort of proceeding permitted under American law prior to the institution of a lawsuit." DIGEST, supra, at 873. See also SPECIAL Commission REPORT, supra, at 1427-28. The members of the Special Commission recommended that contracting nations either make no Article 23 declaration or restrict its application along British lines so that it prohibited only fishing for nonspecific evidence. Id; see also Digest supra, at 875.

West Germany and France, however, appear to have rejected the Special Commission's recommendation. These two countries are currently enforcing Article 23 in such a manner as to preclude pretrial discovery of almost all documents, regardless of whether the request is for specific evidence. See Batista, supra note 33, at 65-69 (discussing French interpretation of Article 23); Shemanski, supra note 11, at 480-83 (discussing West German application of its Article 23 declaration).

${ }^{36}$ Hague Evidence Convention, supra note 3, at Article 27.

37. See infra text accompanying notes 69-76. 
because the Federal Rules of Civil Procedure do provide specific mechanisms for obtaining foreign evidence, ${ }^{38}$ Americans courts have viewed the procedures specified by the Hague Evidence Convention as discretionary.

\section{Judicial Construction of the Hague Evidence Convention}

Although the Hague Evidence Convention has been in force in the United States for over a decade now, few reported cases assess the applicability of its provisions to discovery abroad. One reason for the dearth of case law is that in the first few years after the United States ratified the treaty in 1972, only a handful of other nations also adopted it. $^{39}$ Moreover, American courts and litigants, unfamiliar with the provisions of the Convention and perhaps apprehensive as to the scope of discovery available under its terms, have tended to resort to discovery procedures authorized by federal or state rules of civil procedure.

\section{A. State Court Decisions}

State courts have almost uniformly interpreted the Hague Evidence Convention as providing discretionary mechanisms by which evidence situated in foreign state may be obtained. ${ }^{40}$ Volkswagenwerk $A k$ tiengesellschaft v. Superior Court ${ }^{41}$ and Piergury GmbH $\mathcal{E}^{2}$ Co. KG v. Superior Court ${ }^{42}$ are examples of state cases in which defendants have

38 Pursuant to Rule 33, for example, a party can serve written interrogatories directly on another party located in a foreign country without judicial intervention. Under the Hague Evidence Convention, by contrast, a party would be required to ask the forum court to request assistance to obtain evidence from the designated authorities in the foreign country through a letter of request under Article 1. The party could also specify the questions it wanted answered under Article 3, thus accomplishing the same result but probably with more delay and possibly with more cost. For a detailed discussion of the costs of discovery under the Hague Evidence Convention, see Note, Comparison with Federal Rules, supra note 5, at 396-97.

39 By 1980, only seven countries had ratified the Convention. See Augustine, supra note 14 , at $121 \mathrm{n} .104$.

${ }^{40}$ In addition to the cases discussed in the text, other state court decisions regarding the application of the Hague Evidence Convention include Van Dongen v. Arburg Maschinenfabrik Hehl \& Sohne GmbH \& Co., KG, No. L-71021-81 (N.J. Super. Ct. Law Div. July 1, 1983) (protective order granted requiring parties first to comply with Hague Evidence Convention); McKenna v. Fiat Societa per Azioni, No. 81-2676 (Pa. Ct. of C.P. July 20, 1983) (protective order to comply with Hague Evidence Convention denied). But see Gilbert v. Josef Timmer Mfg. Co., No. CV 81-2340 (Ala. Cir. Ct. July 5, 1983) (protective order granted requiring that discovery proceed only in compliance with the Hague Evidence Convention).

11123 Cal. App. 3d 840, 176 Cal. Rptr. 874 (Cal. Ct. App. 1981).

42137 Cal. App. 3d 238, 186 Cal. Rptr. 876 (Cal. Ct. App. 1982). 
protested that certain discovery orders, requiring the gathering of evidence in West Germany pursuant to Galifornia discovery rules, failed to comply with the Hague Evidence Convention. In Volkswagenwerk, a California appeals court held that the Convention merely provides an "alternative means of obtaining evidence from within West Germany" and that the nations ratifying the Convention had not intended to create a "preemptive and exclusive rule of international evidence-gathering."43

From its reading of Article 27, the court concluded that the Convention did not establish "a fixed rule but rather a minimum measure of international cooperation." The court reasoned that principles of international comity dictate that the procedures established by the Convention were the "obvious and preferable" means for obtaining foreign evidence. ${ }^{48}$ The court thus held that the party seeking discovery must initially comply with the provisions of the Hague Evidence Convention. ${ }^{46}$ The court stressed, however, that requiring preliminary compliance with the Convention was an exercise of "judicial self-restraint" and that a California court had power to order discovery against a foreign party over which it had personal jurisdiction even though the discovery procedure was not specified in the Hague Evidence Convention. ${ }^{47}$

Much of the same result was reached in Pierburg by a different California appeals panel. In that case a West German defendant who had been served written interrogatories by an American plaintiff objected that the interrogatories failed to conform to the terms of the Hague Evidence Convention. Agreeing with the conclusion of the Volkswagenwerk court, the court held that a state court "should require litigants seeking. . . discovery to first attempt to comply with the Convention before allowing the litigant to disregard it."38

\section{B. Federal Court Decisions}

The first reported decision resolving a conflict between the Hague Evidence Convention and the Federal Rules of Civil Procedure was Lasky v. Continental Products Corp. ${ }^{49}$ In Lasky a German defendant

13 Volkswagenwerk, 123 Cal. App. 3d at 858-59, 176 Cal. Rptr. at 885-86.

4. Id. at 859, $176 \mathrm{Cal}$. Rptr. at 886. Such an interpretation of Article 27, however, is misguided. See infra text accompanying notes 72-74.

${ }^{45} \mathrm{Id}$. at 858, $176 \mathrm{Cal}$. Rptr. at 885 .

16 Id. at 859, $176 \mathrm{Cal}$. Rptr. at 885-86.

17 Id. at 860, $176 \mathrm{Cal}$. Rptr. at 885-86.

48 Piersburg, 137 Cal. App. 3d at 240, 186 Cal. Rptr. at 877.

to 569 F. Supp. 1227 (E.D. Pa. 1983). Two earlier federal court cases had referred to the Hague Evidence Convention in addressing motions to dismiss actions on forum non conveniens grounds. In Pain v. United Technologies Corp., 637 F.2d 775 
sought a protective order against interrogatories and a request for the production of documents served by the plaintiff. The court held that there was no conflict between the Convention and the Federal Rules because it interpreted the Convention as "permissive and not mandatory." 27 of the Convention as permitting a signatory nation not only to allow more liberal discovery within its own borders, but also to order discovery broader than that allowed by the Convention in other contracting states. ${ }^{\text {si }}$

Two other federal cases, both decided in 1983, reach different conclusions from that in Lasky, although neither goes so far as to hold that the Hague Evidence Convention provides the exclusive means of procuring evidence located in other contracting states. In Schroeder v. Lufthansa German Airlines, ${ }^{\mathrm{b2}}$ a federal district court relied heavily on the reasoning of the California courts in Volkswagenwerk and Piersburg to hold that the "Hague Convention ... provides an obvious and preferable means of obtaining evidence [located abroad]."

(D.C. Cir. 1980), the court affirmed the trial court's grant of the defendant's motion to dismiss a products liability action after the defendant had conceded liability because all the evidence relevant to the defense and extent of damages was located abroad. The court noted that the Hague Evidence Convention was available to help the parties gain access to these materials but concluded that "these mechanisms . . . are far from perfect." Id. at 788. The court cited "numerous exceptions" to the availability of discovery under the Convention that could potentially limit the parties' access to information necessary to a full and fair trial of damages issues, thus necessitating the dismissal of the action. Id. at 788-90.

It is significant that in Pain the documents and other tangible evidence that were located abroad and that were necessary to a resolution of the question of damages were in the possession and under the control of a Norwegian corporation, which the court found to be beyond the personal jurisdiction of the court. The court emphasized the fact that the defendant's ability to prove affirmative defenses depended on evidence located in Norway that was "immune from the compulsory process of American courts." Id. at 787. There is at least an implication that the court might have reached a different conclusion had the documents been located abroad but under the control of a party to the action over whom the court had personal jurisdiction. This further implies that the court would have felt justified in ignoring or waiving the applicability of the Hague Evidence Convention under such circumstances.

In Hodson v. A.H. Robins Co., 528 F. Supp. 809 (E.D. Va. 1981), another forum non conveniens case, the court discussed the Hague Evidence Convention briefly, noting that it was a "less than perfect" system that would not "completely replicate the access to evidence which would exist if all relevant material were located in this country." Id. at 820 . In refusing to dismiss the action as inconvenient, however, the court concluded that similar problems would exist were the situation reversed and that the Hague Evidence Convention provided the parties with "reasonable procedures by which to obtain evidence present in a foreign forum." Id.

so Lasky, 569 F. Supp. at 1228.

s1 Id. As in the state court decisions, see supra text accompanying note 44 , this reasoning misinterprets Article 27. See infra text accompanying notes 72-74.

${ }_{32} 18$ Av. Cas. (GCH) 17,222 (N.D. Ill. Sept. 15, 1983).

${ }^{68} \mathrm{Id}$. at 17,223 (emphasis added). 
the plaintiff to proceed with discovery in compliance with the Hague Evidence Convention, ${ }^{\text {s4 }}$ but it refused to rule whether "the Convention is a preemptive and exhaustive rule of evidence gathering . . .".58 The court disposed of the motion before it for a protective order by holding that the plaintiff's initial discovery requests, at least, must comply with the Hague Evidence Convention. ${ }^{\text {se }}$

A different federal district court concluded, in Philadelphia Gear Corp. v. American Pfauter Corp., ${ }^{57}$ that "the proper exercise of judicial restraint requires that the avenue of first resort for plaintiff be the Hague Convention." obtain evidence abroad must comply with the Hague Evidence Convention rather than the Federal Rules of Civil Procedure, the court expressly disagreed with the decision reached in Lasky, and particularly with that court's construction of Article 27 of the Convention. ${ }^{58}$ The court in Philadelphia Gear construed Article 27 "in light of the underlying policies" of Convention ${ }^{60}$ and concluded that "it permits only the country in which the evidence is being sought to supplement unilaterally the convention procedures with its internal rules." ${ }^{\text {"1 }}$

The Supreme Court has not yet decided a case involving a conflict between the Hague Evidence Convention and the Federal Rules of

54 Plaintiff was ordered to "draft for this Court's entry, a Letter of Request pursuant to the Convention." Id. at 17,224.

ss Id. at 17,224 n.1. The Court gave some clue to its sentiments on the issue by using the term "postures" to describe the defendant's position that the Convention should be construed as the exclusive discovery method. See id.

${ }^{86} \mathrm{Id}$. at 17,244 .

67 No. 82-5500 (E.D. Pa. Nov. 16, 1983) (motion to compel answers to interrogatories and production of documents denied).

s8 Id. slip op. at 5-6 (footnote omitted) (emphasis added).

60 Id. at 5 n.3; see supra notes 50-51 and accompanying text.

eo Id. at 4. The underlying policies of the Convention, according to the court, are uniformity of procedure in obtaining evidence in foreign countries and reconciliation of "markedly different discovery procedures that exist in common law countries, such as the United States, and civil law countries, such as West Germany." Id. at 2. See also id. at 4 n.2.

62 Id. at 4. There have also been some unreported decisions resolving conflicts between the Hague Evidence Convention and the Federal Rules of Civil Procedure. See, e.g., Rockwell Int'l. Corp. v. Costruzioni Aeronautiche Giovanni Agusta, S.P.A. \& SNFA, No. 81-3984 (E.D. Pa. May 20, 1983) (plaintiff ordered to proceed with discovery by letters in compliance with Hague Evidence Convention); Kantor v. Cycles Peuqeot, S.A., No. 81-0423, slip op. at 5 n.7 (D.R.I. Apr. 14, 1982) (despite recognition by court of potential increase in cost and burden, plaintiff ordered to pursue discovery in conformance with Convention procedures, with reservation by court of power to order additional discovery should plaintiff be unable to obtain all information sought); McKenna v. Fiat Societa per Azioni, No. 81-2676, slip op. at 4 (Pa. Ct. of C.P. July 20, 1983) (defendant's motion for protective order denied and plaintiff's motion to compel answers to interrogatories granted because Hague Evidence Convention "is not controlling in the instant case"). 
Civil Procedure. There is, however, some indication of how at least two members of the Court would react if presented with such a problem. In Volkswagenwerk A. G. v. Falzon, ${ }^{62}$ Justice O'Connor, acting as a Circuit Justice, granted a stay of a state court order permitting plaintiffs to attempt to take depositions of German citizens in Germany over the defendant's objections that such action would violate the Hague Evidence Convention." ${ }^{\text {"6s }}$ In an earlier proceeding in the same case, Chief Justice Burger had granted a stay pending disposition of Volkswagenwerk's application for leave to appeal the discovery order before the Supreme Court of Michigan. ${ }^{64}$

Justice O'Connor reasoned that Chief Justice Burger "must have concluded that there was a substantial chance that four Justices would agree to consider the case on the merits, that there was a significant chance that the applicant would prevail, and that the injury resulting from the denial of a stay would be irreparable."

Since the question on the merits had not changed, Justice

${ }^{62} 103$ S. Ct. 1810 (O'Connor, Gircuit Justice 1983).

6s Id. at 1810 . Justice O'Connor's decision outlined the rather complicated procedural history of this case. The discovery order had been entered by a Michigan trial court in the case of Falzon v. Volkswagen of Am., No. 78-803-043 NP (Mich. Cir. Ct. Wayne County Oct. 7, 1980). The trial court denied Volkswagenwerk's motion to prevent depositions except in accordance with the Hague Evidence Convention, and the Michigan Court of Appeals denied leave to appeal. Volkswagenwerk then sought review in the Michigan Supreme Court, but the trial court in the meantime ordered that the depositions take place before the Michigan Supreme Court could review the appeal. When plaintiffs filed notice to take the depositions, Volkswagenwerk applied to the Supreme Court of Michigan for an emergency stay and for immediate consideration of the order. When the state court did not act, Volkswagenwerk sought a stay from the United States Supreme Court, which Chief Justice Burger granted in Volkswagenwerk A.G. v. Falzon, No. A-191 (Burger, Circuit Justice, order of Aug. 23, 1982), pending final disposition of the appeal before the Supreme Court of Michigan. The Chief Justice also later denied plaintiffs' motion to vacate the stay. See Volkswagenwerk A.G. v. Falzon, No. A-191 (Burger, Circuit Justice, order of Sept. 2, 1982).

The Supreme Court of Michigan then denied the application for leave to appeal the trial court's original discovery order. See Falzon v. Volkswagen Mfg. Corp. of Am. Nos. 69595 \& 69596 (Mich. Feb. 22, 1983). The stay entered by Chief Justice Burger then expired by its own terms. Volkswagenwerk appealed the Supreme Court of Michigan's decision denying the application for leave to appeal the trial court's discovery order to the United States Supreme Court and also petitioned the Supreme Court of Michigan for a stay of the depositions pending disposition of its appeal. When the state supreme court again did not act, Volkswagenwerk applied to the United States Supreme Court for a stay pending disposition of its appeal. This application was granted by Justice O'Connor. 103 S. Ct. 1810 (O'Connor, Gircuit Justice 1983). Volkswagenwerk's appeal from the Supreme Court of Michigan had been dismissed for lack of jurisdiction. See Volkswagenwerk Aktiengesellschaft v. Falzon, 52 U.S.L.W. 3609 (U.S. Feb. 21, 1984).

64 Volkswagenwerk A.G. v. Falzon, No. A-191 (Burger, Circuit Justice, order of Aug. 23, 1982); see supra note 63.

os Volkswagenwerk A.G. v. Falzon, 103 S. Ct. 1810, 1811 (O'Connor, Circuit Justice 1983) (emphasis added). 
O'Connor concluded that this decision that a stay was appropriate was "the law of the case." ${ }^{\text {"Bs }}$ O'Connor, therefore, granted the stay pending disposition of the application for a stay before the Supreme Court of Michigan. ${ }^{67}$

The implication from Justice O'Gonnor's order is that Chief Justice Burger believed that at least four other members of the Court would join him in ruling on the merits that the Hague Evidence Convention must be complied with in seeking discovery of a foreign national. These orders, however, leave unclear whether the Chief Justice or Justice O'Connor would construe the Hague Evidence Convention as establishing the exclusive means of discovery in other contracting states or merely as a mandatory initial procedure.

\section{Principles of Treaty Interpretation}

Although American court opinions have interpreted the Hague Evidence Convention as providing, at best; a suggested mode for taking foreign evidence, the Convention was actually intended to provide an exclusive mechanism by which foreign evidence may be obtained. While the language of the document is ambiguous on this point, principles of treaty interpretation, as well as American constitutional doctrine on the role of ratified treaties vis-à-vis existing statutes, mandate an exclusive reading of the Convention.

\section{A. The Hague Evidence Convention Was Meant to be Exclusive}

The Supreme Court has held that "when the meaning of a treaty is not clear, recourse may be had to the negotiations, preparatory works, and diplomatic correspondence of the contracting parties to establish its meaning." pelling an exclusive reading of the Hague Evidence Convention. There is, however, documentation offering some guidance for interpreting Article 27 of the Convention-an Article crucial to the determination of this issue. ${ }^{68}$

Article 27 provides that

68 Id.

67 See supra note 63.

os Arizona v. California, 292 U.S. 341, 359-60 (1934). Similarly, both the Second Restatement of the Foreign Relations Law of the United States, RESTATEMENT (SECOND) of Foreign Relations Law of the United States \& 147(c)(1), (d) (1965), and the Vienna Convention on the Law of Treaties, opened for signature May 23, 1969, reprinted in 8 INT'L LEgAL MATERIAIs 679 at Article 32, provide that courts may resort to the negotiating history in interpreting a treaty.

${ }^{\circ}$ See supra text accompanying notes $44-46,51$ \& 59-61. 
The provisions of the present Convention shall not prevent a Contracting State from-

(b) permitting, by its internal law or practice, any act provided for in this Convention to be preformed under less restrictive conditions;

(c) permitting, by its internal law or practice, methods of taking evidence other than those provided for in this Gonvention. ${ }^{70}$

Some American courts have interpreted this article as applying both to states seeking foreign evidence and to states in which such evidence is located. ${ }^{21}$ This interpretation of Article 27 has provided a fundamental rationale for a permissive construction of the treaty, whereby procedures specified by the Convention may be disregarded in favor of more liberal American discovery rules. It is apparent, however, that the drafters of the Convention intended a narrower construction of the Article. While Article 27 was intended to give states in which evidence is situated discretion to permit broader discovery within their borders, it was not intended to give states seeking foreign evidence the power to order broader discovery. Since broader discovery is not authorized, the Convention sets forth the only means by which foreign evidence may be obtained.

Philip Amram; the official Rapporteur of the Hague Evidence Convention and co-chairman of the drafting committee described Article 27(b)'s scope, in his Rapporteur's Report, as applying only to the "State of execution."72 Later in the Report, in discussing the importance of Article 27, Amram indicated that the Article was "designed to preserve existing internal law and practice in a Contracting State which provides broader, more generous and less restrictive rules of international cooperation in the taking of evidence for the benefit of foreign courts and litigants."'73

Amram's interpretation of Article 27(b) would permit the state of execution to allow foreign consuls and commissioners broader use of compulsion against a witness within its borders than is generally al-

70 Hague Evidence Convention, supra note 3, at Article 27.

${ }^{71}$ See, e.g., Lasky v. Continental Prods. Corp., 569 F. Supp. 1227 (E.D. Pa. 1983) (see supra text accompanying notes 49-51); Volkswagenwerk Aktiengesellschaft v. Superior Court, 123 Cal. App. 3d 840, 176 Cal. Rptr. 874 (Cal. Ct. App. 1981) (see supra text accompanying notes 41-47).

72 See Rapporteur's Report, supra note 18, at 39-40, 12 INT'L LEGAL MATERIALS at 339 .

78 Id. at 341. 
lowed under Article 18. Amram's interpretation does not, however, extend to the state requesting discovery the same power or the use of compulsion against a witness. ${ }^{74}$ The implication to be drawn from such a reading of Article 27 is that the Convention purports to set forth the sole procedures by which foreign evidence may be obtained.

Also in his Report, Amram identified a limitation on other methods of taking evidence that supports a restricted reading of Article 27. These methods-acceptable under, though not explicitly authorized by, Article 27-include traveling to the foreign country to take a deposition of a willing witness, briefing local counsel in the foreign country to examine a witness, and conducting an inspection of property located in the foreign country with an expert. "The only conditions are that the State of execution will permit this ...."7s

Amram gave basically the same message to a Plenary Session of the Hague Conference, held October 25-26, 1968, when he reported on the work of the Committee that had drafted the text of the Hague Evidence Convention:

Mr. Amram emphasized that . . . the Convention provided for a degree of flexibility wider than most of the Conventions established by the Conference. Thus any State which became a Party to the Convention had complete freedom to offer unilaterally to any other State, with or without reciprocity, any judicial assistance wider than the minimum presented in the Convention. This, the United States, for example, did and would continue to do, under its internal law and procedures. ${ }^{76}$

The inference to be drawn from the Rapporteur's interpretations of Article 27 and the Convention as a whole is that the Convention estab-

74 Id. at 339.

75 Id. at 342. Amram also gave an example of courts in New York and Chicago appointing German and Italian judges as commissioners and granting them compulsion against German and Italian witnesses respectively to allow them to examine these witnesses in New York and Chicago in their own language and without interference from the local courts:

If the internal law and practice of a particular State offers these broad privileges to foreign courts and litigants, which go beyond anything provided for in the Convention, that State may safely sign and ratify the Convention without thereby affecting its right to continue to offer these extra benefits to foreign courts and litigants.

Id. (emphasis added).

70 Conférence de La Haya de Droit Internationale Privé, IV Actes et Documents de la Onzième Session 189 (1970). The draft of the Hague Evidence Convention was approved at the Plenary Session with 21 delegations voting to accept and one (Yugoslavia) abstaining. Id. 
lishes flexible, but exclusive, mechanisms for taking foreign evidence.

Another principle of treaty interpretation asserts that United States courts assessing the domestic implications of the Hague Evidence Convention should examine the meaning American negotiators and enforcers have attributed to the treaty. ${ }^{77}$ Since Phillip Amram was the United States representative to the committee that drafted the treaty, ${ }^{78}$ his interpretation of Article 27 should be of special significance to American courts. This is particularly so in that his report was favorably considered throughout the ratification process. ${ }^{79}$

American courts should also consider the report of the United States delegation to the Convention ${ }^{80}$ and the Secretary of State's Letter of Submittal to the Senate ${ }^{81}$ when deciding the intended scope of the Convention. Both documents contend that the Convention establishes "minimum standards"82 to which signatory states will adhere. At least one court has misinterpreted the minimum standards language and concluded that the mechanisms established by the treaty are the minimum procedures that all receiving states have agreed to execute. ${ }^{83}$ In both documents, however, the references to minimum standards are immediately followed by the assertion that "[a] country may unilaterally offer by internal law and practice, wider, broader, more liberal and less re-

77 The Supreme Court has stated that "[w]hile courts interpret treaties for themselves, the meaning given them by the departments of government particularly charged with their negotiation and enforcement is given great weight." Kolovrat v. Oregon, 366 U.S. 187, 194 (1961).

The Second Restatement of the Foreign Relations Law of the United States elaborates that "[i]n determining the effect of [a treaty] as domestic law," a court may take into account "domestic sources in the formation of an international agreement" such as "[c]ommittee reports, debates, and any other indications of the meaning that the legislative branch has attached to an international agreement in cases where the agreement, as a matter of internal law, requires the assent of the Senate or Congress." RestateMent (Second) of Foreign Relations Law of the United States $§ 151$, comment (b)(i) (1965). In addition, the Restatement provides that a court may take into account other domestic sources such as "[a]spects of the history of the negotiations . . . including unilateral statements of understanding . . . and, probably, internal official correspondence and position papers prepared for the use of the United States delegation to the negotiation." Id. at $\S 151$ comment (b)(ii).

${ }^{78}$ See 1969 Report of the U.S. Delegation, supra note 12, at 805.

79 When recommending the Hague Evidence Convention to the Senate, President Nixon attached the Rapporteur's Report to his Letter of Transmittal. See Message from the President, supra note 5. Also, the Report was mentioned in the report of the Foreign Relations Committee, which recommended that the Senate ratify the treaty. U.S. Cong. Exec. ReP. No 25, 92d Cong., 2d Sess. 3 (1972).

so 1969 Report of the U.S. Delegation, supra note 12.

81 Letter of Submittal, supra note 8.

821969 Report of the U.S. Delegation, supra note 12, at 808; Letter of Submittal, supra note 8, at VI, 12 INT'L LEGAL MATERIALS at 324.

ss Volkswagenwerk Aktiengesellschaft v. Superior Court, 123 Gal. App. 3d 840, 869, 176 Cal. Rptr. 874, 885 (Cal. Ct. App. 1981). 
strictive international assistance." erences in the Delegation Report and Letter of Submittal to minimum standards mean only that a receiving state may offer greater assistance in taking evidence, not that a requesting state can order more than what is set forth by the Convention. ${ }^{85}$

American courts construing the Convention must also give "great weight" ${ }^{386}$ to the positions of the Department of State ${ }^{87}$ and the Justice Department ${ }^{88}$ toward the treaty. In Volkswagenwerk Aktiengesellschaft v. Falzon, ${ }^{80}$ those positions were made clear. In that case, the Department of State refused to transmit a discovery order issued by a Michigan court requiring American consular officials to carry out depositions in West Germany on the grounds that the depositions were contrary to the Hague Evidence Convention. ${ }^{80}$ Both the Department of State and the Department of Justice indicated that they viewed the Convention

84 1969 Report of the U.S. Delegation, supra note 12, at 808.

In the Secretary of State's Letter of Submittal, the reference to the Convention as a set of minimum standards is immediately followed by the statement that "through articles 27,28 , and 32 , [the Convention] provides a flexible framework within which any future liberalizing changes in policy and tradition in any country with respect to international judicial cooperation may be translated into effective change in international procedures." Letter of Submittal, supra note 8, at VI, 12 INT'L LEGAL MATERIALS at 324. In light of this subsequent assertion regarding Articles 27, 28, and 32, the Secretary's reference to the Convention as a minimum standard appears not to suggest that a requesting court can order discovery by procedures other than those recognized by the Convention, but rather that evidence can be gathered outside the Convention only under the less restrictive procedures specifically authorized by Articles 27, 28, and 32. See infra text accompanying note 97 (discussing expressio unius principle of treaty interpretation).

${ }_{83}$ The reference to the Convention as a minimum standard was designed to reassure American lawmakers that "the free and open system of assistance, available in the United States under 28 U.S.C. $\S \S 1781$ and 1782 and $\S 3.02$ of the Uniform Interstate and International Procedure Act, remains unchanged and unrestricted." 1969 Report of the U.S. Delegation, supra note 12 , at 808 .

s6 See supra note 77.

87 The Department of State was the agency responsible for negotiating the treaty and is one of the two agencies charged with its enforcement. See Amram, supra note 5, at 104; Amram, supra note 13, at 651-52. It necessarily is the agency that executes the taking of evidence in foreign countries by United States diplomatic officers and consular agents under chapter II of the Convention. Furthermore, the State Department plays a role under Article 36 of the Convention, which provides that "any difficulties which may arise between Contracting States in connection with the operation of this Convention shall be settled through diplomatic channels." Hague Evidence Convention, supra note 3, at Article 36.

${ }^{88}$ The Department of Justice also helps to enforce the treaty. The Department has been designated as the "Central Authority" that receives letters of request from abroad and forwards them to the executing courts. See Hague Evidence Convention, supra note 3, at Article 32.

80 103 S. Ct. 1810 (O'Connor, Circuit Justice 1983).

-0 Brief for the United States as Amicus Curiae at 6, 11, Volkswagenwerk Aktiengesellschaft v. Falzon, 103 S. Ct. 1810 (O'Connor, Circuit Justice 1983) [hereinafter cited as Brief for the United States]. 
and the procedures for taking evidence established by a bilateral exchange of diplomatic notes ${ }^{21}$ between the United States and West German governments pursuant to Article 32 of the Convention as the exclusive means by which an American court could order discovery in West Germany. ${ }^{82}$

Another principle of treaty interpretation provides that where the language of the agreement is ambiguous, courts may refer to the subsequent practice of the contracting states in order to determine the treaty's meaning. ${ }^{93}$ As we have seen, the subsequent practice of the United States government is to treat the Convention as exclusive. Likewise, the practice of the West German government has been to view the Convention as exclusive. During the proceedings in Falzon, the West German Ambassador in Washington, D.C., sent a letter to the Chief Justice of the Michigan Supreme Court, protesting that the Michigan discovery order violated the Convention. The ambassador wrote,

The United States and the Federal Republic of Germany are parties to the Hague [Evidence] Convention [that] establishes ... the legal framework and procedures for the taking of evidence in Germany for use in civil matters pending in the United States. The Gonvention sets forth the only procedures

91 The text of these diplomatic notes, which reaffirmed that a bilateral exchange of notes in 1955 and 1956 between West Germany and the United States is still in effect after the ratification of the Convention, may be found in AMERICAN BAR Association National Institute, Transnational Litigation: Pracitical ApPROACHES TO CONFLICTS AND ACCOMMODATIONS 1271-81 (1984) [hereinafter cited as Transnational Litigation]. For a discussion of these Diplomatic Notes, see Shemanski, supra note 11, at 477-78.

${ }_{92}$ See Brief for the United States, supra note 90, at 6, 11. James Hergen, an assistant legal advisor for consular affairs at the Department of State, helped attorneys from the Department of Justice prepare the United States's amicus brief. See id. at cover page.

8s "In ascertaining the meaning of a treaty we may look . . . to [the parties'] own practical construction of it." Factor v. Laubenheimer, 290 U.S. 276, 294-95 (1933). This principle has been adopted by both the Second Restatement of Foreign Relations Law of the United States, see Restatement (Second) of Foreign Relations Law OF THE UNITED STATES $§ 147(1)(f)(1965)$, and the Vienna Convention on the Law of Treaties, opened for signature May 23, 1969, art. 31(3)(b), reprinted in 8 INT'L LEGaL Materials 679,692. One commentator has noted that

[t]he [Vienna Convention] entered into force upon ratification by the thirty-fifth state in 1980. Although over half of the signatory states, including the United States, have yet formally to ratify the convention, it is generally accepted that the convention is "already recognized as the authoritative guide to current treaty law and practice." United States President, Message from the President Transmitting the Vienna Convention on the Law of Treaties to Congress, S. Exec. Doc. L., 92d Cong., 1st Sess. 1 (1971).

Koh, Reservations to Multilateral Treaties: How International Legal Doctrine Reflects World Vision, 23 HARv. INT'L L.J. 71, 95 n.88 (1982). 
sanctioned by the German government for the taking of such evidence. ${ }^{94}$

As with the German government, it appears that the subsequent practice of the French government has been to view the Convention as exclusive. Angered by the fact that "the terms of the Hague [Evidence] Convention ... were frequently disregarded by American litigants,"9s the French Senate and National Assembly in 1980 enacted a statute that makes it a criminal offense to request or attempt to solicit evidence of a commercial or technical nature for use in a foreign proceeding in a manner not provided for by the Hague Evidence Convention or other international treaties. ${ }^{88}$

While an exclusive interpretation of the Hague Evidence Convention is compelled by the intentions of the drafters and subsequent practices of the signatory states, several other principles warranting this construction should be noted. The doctrine expressio unius est exclusio alterius asserts that if numerous exceptions to a treaty are specifically set forth, the treaty is intended to exclude other exceptions. The Hague Evidence Convention provides several exceptions to the chapter I and II modes of obtaining evidence: evidence may be taken under other bilateral treaties pursuant to Article 32; the executing state may permit less restrictive discovery pursuant to Article 27; and a variety of limiting declarations are provided for in chapters I and II. ${ }^{97}$ The conclusion to be drawn is that since the drafters did not provide an exception for requesting courts to order foreign discovery on their own terms, such discovery may not be ordered.

An exclusive construction of the Convention is also compelled when the contractual nature of the treaty is examined. The Supreme

94 Jurisdictional Statement and Appendix at 8-9, Volkswagenwerk Aktiengesellschaft v. Falzon, 103 S. Ct. 1810 (O'Connor, Circuit Justice 1983) (emphasis added). See also Brief for the United States, supra note 90, app. at 3a (letter from West German embassy in Washington to the Department of State, requesting the Department of State to help prevent execution of the Michigan discovery orders in Falzon and noting that "[i]t is particularly distressing that such attempt to take depositions in the Federal Republic of Germany is [sic] not been made in accordance with procedures of the Hague [Evidence] Convention ... to which both the United States and the Federal Republic of Germany are parties").

${ }^{98}$ Herzog, The 1980 French Law on Documents and Information, 75 Aм. J. INT'L L. 382, 382 (1981).

os See id. at 382-85; see also Transnational Litigation, supra note 91, at 1329; Batista, supra note 33, at 64-65, 67-69.

97 See Hague Evidence Convention, supra note 3. Of the 22 articles in chapters I and II, seven (Articles 2, 8, 11, 15, 16, 17, and 18) permit a contracting state to make declarations that expand or restrict procedures authorized by the Convention. In addition, Article 33 provides that a contracting state may make a reservation under which it refuses to recognize any of the chapter II mechanisms of gathering evidence. 
Court has held that treaty "obligations should be . . . construed so as to effect the apparent intention of the parties to secure equality and reciprocity between them." tween independent nations," tion in light of the contracting states' justified expectations. Civil law countries made several large concessions in the Hague Evidence Convention. Among the most important is Article 9, which "impose[s] obligations on civil law courts to take evidence 'common-law style,' a method with which they are not familiar."100 Considering that civil law countries even before the Convention enjoyed generous assistance in taking evidence within the United States under federal law, ${ }^{101}$ they would have had little incentive for agreeing to these "common-law style" innovations unless the convention was intended to define and limit the scope of procedures by which common law countries would order discovery within civil law countries. A contractual analysis of the treaty, therefore, supports an exclusive reading of the Convention.

Finally, it makes little sense to interpret the terms of a treaty so as to render the treaty superfluous. If the Convention is construed to establish no more than preliminary guidelines for obtaining foreign evidence, courts could supplant or supplement it at the insistence of one of the parties that the discovery attempted under the Convention was "unsuccessful." 102 Such an interpretation would mean that the Hague Evi-

${ }^{88}$ Factor v. Laubenheimer, 290 U.S. 276, 293 (1933).

${ }^{89}$ Santovincenzo v. Egan, 284 U.S. 30, 40 (1931). Note the repeated references to the "contracting" nations in the Hague Evidence Convention, supra note 3. But see McNaIR, The Law of Treaties 739, 743-44 (1961), cited in Restatement (SecOND) OF Foreign ReLations LAw of the UnITED States § 146 Reporters' Note (1) (1965). McNair argues that interpreting a treaty as a contract (Vertrag) may be appropriate when the treaty is a bilateral agreement, but that that such an approach to interpretation is inappropriate for multilateral treaties. A multilateral treaty, in McNair's view, more closely resembles an act of a legislature for the common good.

100 Amram, supra note 5, at 106. Other major concessions by civil law countries include the chapter II provisions of the Convention. Although civil law countries view the gathering of evidence as a judicial function, see supra text accompanying notes 11 $\& 12$, chapter II provisions increase the powers of consuls to take evidence outside of court and introduce "into the civil law world on a limited basis the concept of taking of evidence by [private] commissioners." Amram, supra note 5, at 105. See also Rapporteur's Report, supra note 18, at 11, 12 INT'L LEgAL MATERIALS at 327.

${ }_{101}$ See 28 U.S.C. $\$ \S 1781,1782$ (1982) (the latest amendments to these laws were enacted on October 3, 1964-several years before the drafting of the Hague Evidence Convention).

102 See supra text accompanying notes $40-48$ \& 52-61. Every court that has thus far entered a written order requiring compliance with the Hague Evidence Convention has indicated that it would consider a motion to compel additional discovery outside of the provisions of the Convention if it appeared that the initial discovery were insufficient. No court has yet decided such a motion.

Since 12 of the 17 signatory nations have adopted some form of Article 23 reservation against executing letters of request seeking pretrial discovery, see supra note 35 , it 
dence Convention could be easily challenged every time it is invoked, eventually rendering even its initial application an empty exercise.

\section{B. The Hague Evidence Convention Supersedes Federal and State Rules of Civil Procedure}

While principles of treaty interpretation compel an exclusive reading of the Hague Evidence Convention, constitutional doctrine dictates that the provisions of the Convention override federal and state ${ }^{103}$ mechanisms for obtaining evidence situated in foreign states. The supremacy clause of the United States Constitution places treaties on an equal footing with statutes. ${ }^{104}$ The Supreme Court has held that

[i]f the treaty contains stipulations which are self-executing, that is, require no legislation to make them operative, to that extent they have the force and effect of a legislative enactment .... By the Constitution a treaty is placed on the same footing, and made of like obligation, with an act of legislation. Both are declared by [the supremacy clause] to be the supreme law of the land, and no superior efficacy is given to either over the other. ${ }^{105}$

Whether a treaty is self-executing depends on whether it requires affirmative legislative action to make its provisions operative. In United States $v$. Enger, ${ }^{108}$ a federal district court ruled on whether the Vienna Convention, a treaty concerning the scope of diplomatic immunity recognized in the United States, was self-executing. The presence of the treaty's detailed provisions and the absence of language requiring congressional implementation legislation led the court to rule that the treaty was self-executing and that, "upon entry into force, it at once

is likely that many attempts at discovery under the terms of the Convention could be deemed "unsuccessful."

${ }^{103}$ Under the supremacy clause, U.S. Consr. art. VI, a treaty ratified by the United States prevails over state law. In fact, the Supreme Court has ruled that a ratified treaty of the United States may pre-empt a state law that simply "impairs the policy" of the treaty. See United States v. Pink, 315 U.S. 203, 230-31 (1942); see also Hines v. Davidowitz, 312 U.S. 52, $62-63$ (1941); Hauenstein v. Lynham, 100 U.S. 483, 488-90 (1879); Ware v. Hylton, 3 U.S. (3 Dall.) 199, 277-80 (1796).

Professor Tribe states that "[u]nder the supremacy clause, it is indisputable that a valid treaty overrides any conflicting state law, even on matters otherwise within state control. Indeed, the treaty controls whether it is ratified before or after the enactment of the conflicting state law." L. TRIBE, AMERICaN Constitutional Law $\S 4-4$, at 168 (1978) (footnotes omitted).

104 U.S. CoNST. art. VI.

${ }^{105}$ Whitney v. Robertson, 124 U.S. 190, 194 (1888).

108472 F. Supp. 490 (D.N.J. 1978). 
became operative as domestic law of the United States."107 Given the detailed provisions of the Hague Evidence Convention and the lack of language requiring implementing legislation, the Convention is a selfexecuting treaty.

When a self-executing treaty and a federal statute conflict, the doctrine of implied repeal asserts that the later-enacted will prevail. ${ }^{108}$ Furthermore, the Supreme Court has held that "a treaty will not be deemed to have been abrogated or modified by a later statute unless such purpose on the part of. Congress has been clearly expressed."100

It is arguable whether the Federal Rules of Civil Procedure have the standing of a federal statute vis-à-vis other federal statutes and treaties. ${ }^{110}$ In any event, no amendment to the Federal Rules of Civil Procedure clearly expressing an intent to modify the Hague Evidence Convention has been enacted since the ratification of the Convention in 1972. For example, Rule 28(b), which describes how depositions may be taken in foreign countries, was last amended in 1963. ${ }^{111}$ According to the doctrine of implied repeal, therefore, the later-enacted Hague Evidence Convention, within its scope, supersedes the Federal Rules of Civil Procedure.

The Supreme Court has also recognized and applied a "canon of construction which teaches that the legislation of Congress, unless the contrary intent appears, is meant to apply only within the territorial jurisdiction of the United States." Such a rule of construction "is based on the assumption that Congress is primarily concerned with domestic conditions." ${ }^{\text {"12 }}$ Under this approach, the general discovery provisions of the Federal Rules of Civil Procedure should be construed as applying

107 Id. at 542.

108 Whitney v. Robertson, 124 U.S. at 194; see also Chae Chan Ping v. United States (The Chinese Exclusion Case), 130 U.S. 581, 600-01 (1889) (later act of Congress forbidding Chinese laborers who had left U.S. from reentering supersedes previous treaties between U.S. and China covering same subject where conflicting); Edye v. Robertson (Head Money Cases), 112 U.S. 580, 599 (1884) (later act of Congress regulating immigration through imposition of head tax supersedes previously existing treaties covering immigration to the extent they are inconsistent).

109 Cook v. United States, 288 U.S. 102, 120 (1933).

110 On the one hand, the Rules Enabling Act provides that "[a]ll laws in conflict with [the Federal Rules of Civil Procedure] shall be of no further force or effect after such rules have taken effect." 28 U.S.C. $§ 2072$ (1982). On the other hand, this provision can be construed as applying only to the original rules, not to subsequent amendments. In Walko Corp. v. Burger Chef Sys., Inc., 554 F.2d 1165 (D.C. Cir. 1977), the court held that "Congress' failure to suspend a proposed rule gives it the force not of a legislative enactment, but of a regulation pursuant to the [Rules Enabling] Act." Id. at 1169 n.29.

111 FED. R. Grv. P. 28(b) advisory committee note (1963 amendments).

112 Foley Bros. v. Filardo, 336 U.S. 281, 285 (1949). See also Blackmer v. United States, 284 U.S. 421, 437 (1932). 
only within the territorial jurisdiction of the United States unless Congress expressly indicates otherwise.

Finally, the conclusion that the Hague Evidence Convention overrides other mechanisms for obtaining foreign discovery is consistent with a principle of both statutory construction and international conflict of law doctrine: lex specialis derogat generali (a particular law prevails over a general rule). ${ }^{113}$ Application of this principle leads to the conclusion that the Hague Evidence Convention, a treaty designed to address the specific problems of discovery from foreign countries, supersedes rules governing the more general field of discovery of evidence for use in United States courts.

\section{CoNCLUSION}

The Hague Evidence Convention establishes an exclusive set of procedures by which evidence situated in foreign states may be obtained. Although a number of American courts have ruled otherwise, it was the intention of the states participating in the Convention that an exclusive mechanism for taking evidence be created. An examination of the Rapporteur's Report, the subsequent positions of three important signatory states, and various principles of treaty interpretation compel this conclusion. As the supreme law of the land, the Hague Evidence Convention may not be ignored by American courts and litigants seeking evidence abroad.

American courts that by-pass the terms of the Convention in favor of more familiar domestic discovery procedures unnecessarily exacerbate the tensions between differing judicial systems. One co-chairman of the drafting committee of the Convention has stated that "[i]t was not possible to ask the Continental countries to change their public policy and their legal traditions overnight and to permit the same kind of free activity in their countries as we have permitted here."114 By recognizing the exclusive nature of the Hague Evidence Convention, American courts will effectuate the intentions of its drafters and accord the respect that is due to our partners in the treaty.

11 See Akehurst, The Hierachy of the Sources of International Law, 1974-75 BRIT. Y.B. INT'L L. 273, 273.

114 Amram, supra note 13, at 655. See also 1969 Report of the U.S. Delegation, supra note 12, at 806. 


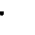

